\title{
Pregnancy outcome in a rare case of complex cyanotic congenital heart disease
}

\author{
Amitha V. Kamat, Sahaja S. Kittur*, Mallikarjun G. Hiremath, S. R. Chandana Murthy
}

Department of Obstetrics \& Gynaecology, Karnataka Institute of Medical Sciences, Hubli, Karnataka, India

Received: 28 December 2014

Accepted: 11 January 2015

*Correspondence:

Dr. Sahaja S. Kittur,

E-mail: drsahajakittur@rediffmail.com

Copyright: (C) the author(s), publisher and licensee Medip Academy. This is an open-access article distributed under the terms of the Creative Commons Attribution Non-Commercial License, which permits unrestricted non-commercial use, distribution, and reproduction in any medium, provided the original work is properly cited.

\section{ABSTRACT}

A 28 year old primigravida with the very rare congenital heart condition of single ventricle with single atrium presented with 34 weeks gestation, and underwent caesarean section with minimal morbidity. As the condition is not known for survival into adulthood, the carrying of a pregnancy successfully to near term makes this an even rarer case.

Keywords: Cyanotic heart disease, Pregnancy, Complex congenital heart disease

\section{INTRODUCTION}

Complex congenital cyanotic heart disease comprising single ventricle with single atrium together is a very rare entity and very few of these are known to survive till adulthood. This case is being reported for the rarity of not only survival into adulthood but also the sustenance of a pregnancy to near term. Pubmed search revealed only 2 cases in the world till date.

\section{CASE REPORT}

A 28 year old primigravida came to the OBG OPD with the history of 8 months amenorrhoea, with complaints of swelling of feet, giddiness and easy fatiguability since one week. Patient had been diagnosed to have complex cyanotic congenital heart disease at the age of 6 years when she had presented with complaints of dyspnoea and was on regular infective endocarditis prophylaxis since then.

On examination, she had tachycardia (120/min), loud $\mathrm{S}_{1}$ and mid diastolic murmur in mitral area and ejection systolic murmur in aortic area of grade 3 and fine basal crepitations. $\mathrm{SPO}_{2}$ was maintained between 70 to $80 \%$.
She had mild pre eclampsia. Patient belonged to NYHA class II.

Her 2D ECHO showed-complex congenital cyanotic heart disease with large non-restrictive ASD (almost single atrium) with bidirectional flow, large nonrestrictive VSD (almost single ventricle) with bidirectional flow with aortoventricular valve regurgitation, pulmonary valve atresia, SVC and IVC draining into right atrium, common pulmonary vein confluence draining into roof of single atrium on left side, a single great vessel arising from ventricle with coronaries-aorta, main trunk of pulmonary artery not visualised, but branches of pulmonary artery seen getting filled by multiple aorto pulmonary collaterals and right sided aortic arch. Obstetric scan showed SLIUG of 34 weeks with IUGR with oligohydramnios. Hemoglobin$13.1 \%$, PCV-43.9\%. MRI and chest X-ray were also done (Figures 1, 2 and 3).

Elective caesarean was planned, but the patient went into spontaneous labour at 36 weeks 6 days gestation and emergency LSCS was done under graded epidural anaesthesia and local infiltration of $2 \%$ lignocaine. Total duration of caesarean was 13 minutes 20 seconds and a live baby of $2 \mathrm{~kg}$ was extracted. Throughout the 
procedure, CVP was maintained between 8-12 $\mathrm{cm}$ of water. Post operatively she had persistent tachycardia $(160-180 / \mathrm{min})$ and desaturation, was shifted to cardiac ICU and started on diltiazem. On day 3 of LSCS, when diltiazem was discontinued she developed breathlessness and tachycardia (140-150/min). Diltiazem was restarted. She remained asymptomatic after that. The patient was discharged after 1 month with a live baby and cardiac condition similar to that at the time of admission.

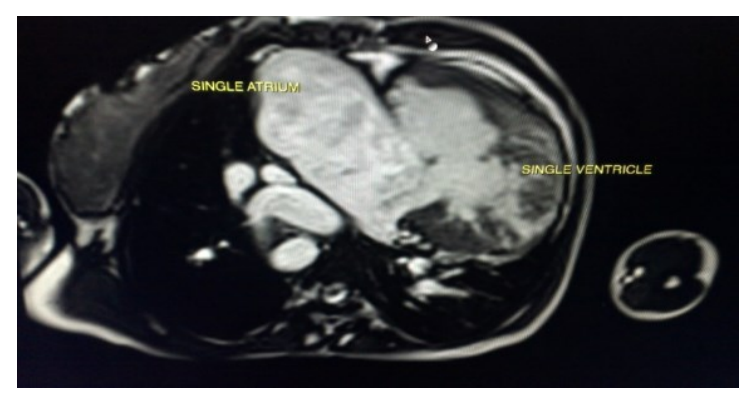

Figure 1: MRI thorax plain.

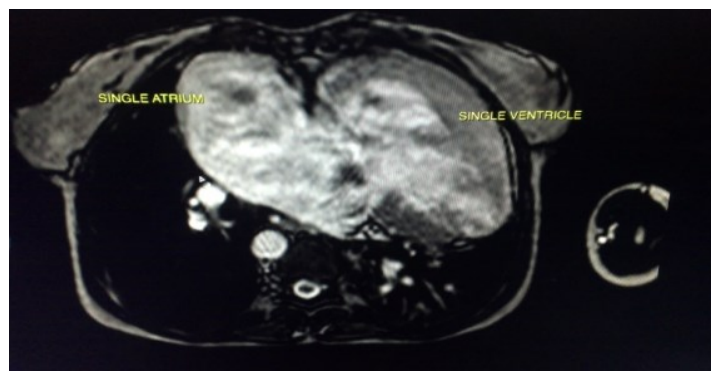

Figure 2: MRI thorax plain.

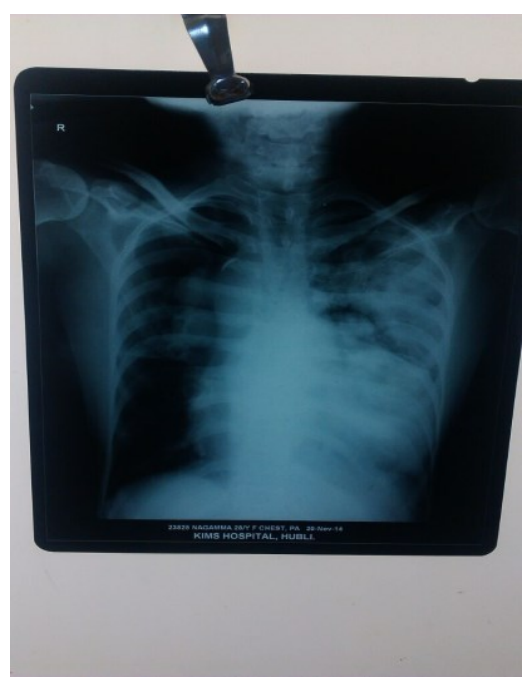

Figure 3: X-ray chest-moderate cardiomegaly with right sided predominance, aorta dilated with right sided aortic arch, non-visualized pulmonary conus.

\section{DISCUSSION}

Single Ventricle (SV) defects, including common inflow of both the atria emptying into one ventricle, occur at an incidence of 0.05-0.1/10000 live-births. ${ }^{1}$

Common atrium is a rare variety of interatrial communication which forms a type of endocardial cushion defect characterised by deficient atrial septum, the vestigial remnants sometimes remain as diaphanous strands of tissue. ${ }^{2,3}$ Common atrium is very rarely seen in patients with $\mathrm{SV}{ }^{3}$

In patients with common atrium and $\mathrm{SV}$, there is mixing of arterial and venous blood in the common cardiac chamber which causes severe cyanosis and hypoxia in these patients. 3,4

The prognosis of SV with common atrium is poor with high mortality rate of up to $50 \%$ in infancy. ${ }^{5}$ The median survival of single ventricle of LV morphology is 14 years, while that of the right ventricle morphology is 4 years. $^{5}$

\section{Funding: No funding sources Conflict of interest: None declared Ethical approval: Not required}

\section{REFERENCES}

1. Nabati M, Bagheri B, Habibi V. Coincidence of total anomalous pulmonary venous drainage to the superior vena cava, common atrium, and single ventricle: a very rare condition. Echocardiography. 2013;30:e98-101.

2. Rastelli GC, Rahimtoola SH, Ongley PA, McGoon DC. Common atrium: anatomy, hemodynamics, and surgery. J Thorac Cardiovasc Surg. 1968;55:834-41.

3. Munoz-Armas S, Gorrin JR, Anselmi G, Hernández PB, Anselmi A. Single atrium. Embryologic, anatomic, electrocardiographic and other diagnostic features. Am J Cardiol. 1968;21:639-52.

4. Kinare SG, Sivaraman A, Deshpande J. Single ventricle (morphologic study of 21 cases). Indian Heart J. 1989;41:301-6.

5. Patra S, Agrawal N, Usha MK, Jayaranganath M. Common atrium with single ventricle: a rare combination of two uncommon complex congenital heart diseases. BMJ Case Rep. 2013;2013.pii: bcr2013200424.

DOI: $10.5455 / 2320-1770.1 j r \operatorname{cog} 20150247$

Cite this article as: Kamat AV, Kittur SS, Hiremath MG, Chandana Murthy SR. Pregnancy outcome in a rare case of complex cyanotic congenital heart disease. Int J Reprod Contracept Obstet Gynecol 2015;4:250-1. 